\title{
Effects of the ENSO on the Variability of Precipitation and Air Temperature in Agricultural Regions of Mato Grosso State
}

\author{
João Danilo Barbieri ${ }^{1}$, Rivanildo Dallacort ${ }^{2}$, Paulo Sérgio Lourenço de Freitas ${ }^{3}$, Dejânia Vieira de Araújo ${ }^{2}$, \\ Rafael Cesar Tieppo ${ }^{4} \&$ William Fenner ${ }^{5}$ \\ ${ }^{1}$ Department of Agronomy, State University of Maringá, Maringá, Brazil \\ 2 Department of Agronomy, State University of Mato Grosso, Tangará da Serra, Brazil \\ ${ }^{3}$ Department of Agronomy, State University of Maringá, Maringá, Brazil \\ ${ }^{4}$ Department of Agronomy, State University of Mato Grosso, Tangará da Serra, Brazil \\ ${ }^{5}$ Faculty of Agronomy and Zootechnic, Federal University of Mato Grosso, Cuiabá, Brazil \\ Correspondence: João Danilo Barbieri, Department of Agronomy, State University of Maringá, 5790 Colombo \\ Avenue Maringá, Brazil. E-mail: jd.barbieri@hotmail.com
}

Received: February 14, 2019

Accepted: April 24, $2019 \quad$ Online Published: June 30, 2019

doi:10.5539/jas.v11n9p91

URL: https://doi.org/10.5539/jas.v11n9p91

\begin{abstract}
The analyze of the El Niño, La Niña, and Neutral years phenomena and their influence on the temporal distribution of precipitation and air temperature is of great importance in agricultural systems, with the view to adapt crop management in order to reduce the risks of losses, optimizing rainwater and contributing to food security. The aim of this paper was to characterize variations in annual, monthly, and dekads rainfall in normal years and in those in the two extreme ENSO events in the municipalities of Tangará da Serra, Rondonópolis, and Sinop, in Mato Grosso state. Historic data were used, from INMET and ANA, covering 1970 to 2016. Probable annual precipitation was determined via the gamma distribution. In the three municipalities studied, the period considered as rainy falls between October and April and the dry season falls between May and September. The average annual rainfall for the municipalities is 1800,1900 , and $1500 \mathrm{~mm}$, for Tangará da Serra, Sinop, and Rondonópolis, respectively. The effects of the ENSO, besides causing a $100 \mathrm{~mm}$ reduction in average annual precipitation, also cause little summers ("veranicos") in the months of November and February. The municipalities of Tangará da Serra, Rondonópolis, and Sinop presented high levels of rainfall in Neutral years. The effects of the ENSO reduce rainfall levels but increase the number of rainy days. The Neutral years are more suitable to agriculture at regions of Mato Grosso State, followed by El Niño years, with concentrated rainy period and La Niña, with higher occurrence of veranicos, that maybe mitigated with use of irrigations systems.
\end{abstract}

Keywords: climatic phenomena, distribution probability, El Niño, La Niña, Neutrals

\section{Introduction}

Mato Grosso state, one of the richest in Brazil in terms of diversity, with three of the most important biomes in the country (Cerrado, Pantanal, Amazon), has presented accelerated economic growth in the last decades, together with demographic growth (Marinho et al., 2016). The area is also one of the main agricultural regions in Brazil. At the beginning of the $21^{\text {st }}$ Century, it took over as the biggest producer of grains in the country. The regions of Sinop, Rondonópolis, and Tangará da Serra are municipalities of great agricultural importance (Câmara, 2012).

According to data from "National Supply Company" CONAB (2016), soy productivity in Mato Grosso has declined since 2007, when it was $3100 \mathrm{~kg} \mathrm{ha}^{-1}$ to $2956 \mathrm{~kg} \mathrm{ha}^{-1}$ in the harvest of 2015/2016 growing season. One of the key factors that caused this reduction is climatic variability. CONAB also states that there was a delay in planting in various states and the occurrence of "veranicos", periods of time with $\mathrm{x}$ feature, generated a reduction of the last harvest. Due to the increase in area, production in the 2015/16 harvest, estimated at 96.9 million tons, is greater in relation to the 2014/15 harvest, but with lower productivity per unit area.

Alves et al. (2016), evaluated the perception of agricultural producers and identified changes in rainfall pattern as the main factor limiting productivity, since certain conditions may increase the incidence of pests and diseases, 
as well as the scarcity of rainfall during critical periods of crops.

The Mato Grosso state carried out much of the cultivations without irrigation, depending exclusively on precipitation for grain production. Ramos et al. (2015) state that the effects of the El Niño Southern Oscillation (ENSO) cause greater variability in rains and can favor or jeapordize crop development.

According to Podestá et al. (1999), the occurrence of the ENSO is linked to the strong ocean-atmosphere connection that occurs over the equatorial region of the Pacific Ocean. The effects of the ENSO start to be felt in the second semester of the year and normally extend into the first half of the following year, and are composed of two distinct phases: the El Niño or hot phase, and the La Niña or cold phase (Berlato, Farenzena, \& Fontana, 2005).

The ENSO phenomenon involves ocean-atmosphere interaction, associated with alterations in normal sear surface temperature (SST) patterns and trade winds in the Equatorial Pacific region, between the Peruvian coast and Australia. During the negative phase (La Niña) rains are generally lower than climatologically normal, and in the positive phase (El Niño) they are generally above normal (Grimm et al., 2000; Berlato \& Fontana, 2003; Neto, Barbosa, \& Araújo, 2007; Ramos et al., 2015).

Decisions to begin planting and about what crop to start the harvest, are taken by producers depending on the price of inputs and other economic factors, and not taking into consideration the occurrence of climatic phenomena such as the ENSO, which can modify the dynamic of planting in regions of the state. Therefore, the aim of this paper was to identify the variability of rains when the ENSO occurs, in the municipalities of Tangará da Serra, Rondonópolis, and Sinop, by observing the rainfall probabilities when these phenomena take place.

\section{Method}

\subsection{Data}

The data for this paper were provided by the National Institute of Meteorology (INMET) and the National Water Agency (ANA), with stations located at the geographical coordinates shown in Figure 1. Daily data on precipitation and mean air temperature were used, of the entire period back to 2016. To fill in the gaps, the CLIMA software (Faria et al., 2003) developed by the Agronomic Institute of Paraná (IAPAR), was used. Analyses of annual, monthly, and dekads averages and standard deviations were subsequently carried out for the data discussion.

The municipalities were chosen due to the large historical meteorological data series and their location, which covers three biomes in the state (Amazon, Carrado (savanna vegetation) and Pantanal), representing the most important centers of grains production in Mato Grosso state (Figure 1).
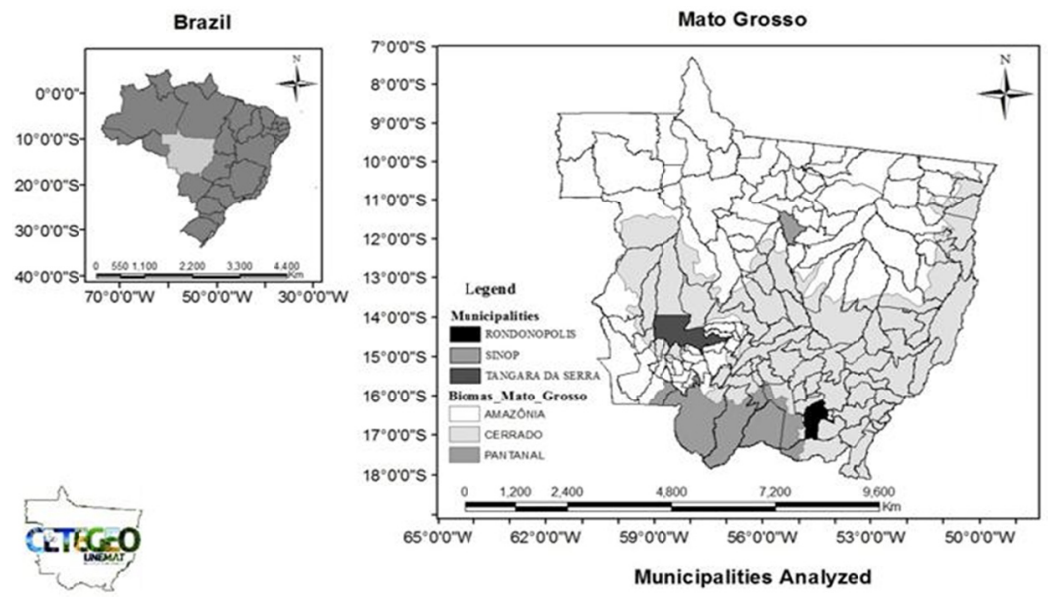

Figure 1. Spatial location and political boundaries of the municipalities of Tangará da Serra,

Rondonópolis and Sinop

\subsection{Probability Analysis}

An analysis of the occurrence of dry and rainy days was carried out based on the methodology proposed by Sans et al. (2001), who consider days with precipitation lower than $5 \mathrm{~mm}$ as dry days and those with precipitation equal to or greater than $5.1 \mathrm{~mm}$ as rainy. 
The climate of the regions is classified as AwA, BwA, and CwA according to Koppen classification, for Tangará da Serra, Sinop, and Rondonópolis, respectively; that is, it is a hot and humid climate, with a rainy season in the summer and drought in the winter, thus characterizing it as seasonal (Souza et al., 2013).

To determine the different levels of rainfall probability, the incomplete gamma distribution probabilistic model described by Thom (1958) was used, in which the density of probability function is given as shown in Equation 1.

$$
G(y)=\frac{1}{\beta^{\gamma} \times \Gamma(\alpha)} \times x^{\alpha-1} e^{-x / \beta}
$$

where, $\alpha$ : form parameter (dimensionless); $\beta$ : scale parameter $(\mathrm{mm})$; e: Napier's logarithm base; $\mathrm{x}$ : total precipitation $(\mathrm{mm})$; and $\Gamma(\alpha)$ : symbol of the gamma function, defined as in Equation 2.

$$
\Gamma(\alpha)=\sqrt{2 \pi \alpha} \cdot \alpha^{\alpha} e^{\alpha}\left(1+\frac{1}{12 \alpha}+\frac{1}{288 \alpha^{2}}-\frac{139}{51840 \alpha^{3}}\right)
$$

The form $(\alpha)$ and scale $(\beta)$ parameters, which enable the cumulative gamma distribution to be calculated for a given random variable, were estimated using the moments method, usually used to equate the average $\overline{\mathrm{X}}$ and the variance S2 of the sample with the average, as shown in Equations 3 and 4 (Assis et al., 1996).

$$
\begin{gathered}
\alpha=\frac{\bar{X}^{2}}{S^{2}} \\
\beta=\frac{S^{2}}{\bar{X}}
\end{gathered}
$$

The probable precipitations were then determined at $10,25,50,75$, and $90 \%$ probability, for subsequent analysis and discussion of the data.

\subsection{ENSO Phenomena}

Precipitation was not analyzed in accordance with the normal calendar year, as this phenomenon occurs from July of one year to June of the next, and so the data were tabulated in order to isolate the period of ENSO interference. The years in which the ENSO phenomena occurred in the period from 1961 to 1992 were characterized by Podestá et al. (1999), and the phenomena occurring after 1992 and until 2003 were described by Berlato, Farenzena, and Fontana (2005), in accordance with the Podestá et al. (1999) methodology. Those years in which there was no influence of ENSO phenomenon were considered neutral (Table 1).

Table 1. List of years used at work classified by Podestá at al. (1999) and Berlato, Farenena and Fontana (2005)

\begin{tabular}{lllllll}
\hline Event Occurred & Years & & & & & \\
\hline \multirow{2}{*}{ EL NIÑO } & $1977-1978$ & $1978-1979$ & $1979-1980$ & $1982-1983$ & $1986-1987$ & $1987-1988$ \\
& $1990-1991$ & $1991-1992$ & $1992-1993$ & $1994-1995$ & $1997-1998$ & $2002-2003$ \\
& $2004-2005$ & $2006-2007$ & $2009-2010$ & $2014-2015$ & $2015-2016$ & \\
\multirow{2}{*}{ LA NIÑA } & $1970-1971$ & $1971-1972$ & $1972-1973$ & $1974-1975$ & $1975-1976$ & \\
& $1976-1977$ & $1983-1984$ & $1984-1985$ & $1973-1974$ & $1988-1989$ & \\
\multirow{2}{*}{ NEUTRAL } & $1995-1996$ & $1998-1999$ & $1999-2000$ & $2000-2001$ & $2007-2008$ & \\
& $1980-1981$ & $1981-1982$ & $1985-1986$ & $1989-1990$ & $1993-1994$ & \\
& $1996-1997$ & $2001-2002$ & $2003-2004$ & $2005-2006$ & $2008-2009$ & \\
\hline
\end{tabular}

Note. Data adapted of INPE/CPETEC (2016).

The determination and analysis of the annual rainfall probability were carried out using the gamma distribution probabilistic method, characterized by Thom (1958) and recently used by various authors, such as Silva et al. (2007), Dallacort et al. (2011), and Ramos et al. (2015), using 10, 25, 50, 75, and $90 \%$ probability levels, for the three municipalities in Mato Grosso, and observing pattern in ENSO years.

\section{Results and Discussion}

\subsection{Pattern of Average Annual, Monthly, and Dekads Rainfall}

The average annual precipitation observed in the period from 1970 to 2016 in the municipalities of Tangara da Serra, Sinop, and Rondonópolis had a variation in rainfall levels when under the effect of the ENSO. For all the municipalities, Neutral years have higher annual averages, reaching a difference of $100 \mathrm{~mm}$. Similar results were 
also observed by Ramos et al. (2015) in the municipality of Diamantino.

In the municipality of Tangará da Serra, the variation was from 1940 to $1801 \mathrm{~mm}$, considered small for annual averages. Rondonópolis have $100 \mathrm{~mm}$ less in Neutral years.

High average annual variability can be observed by the variance in the data, with a maximum value of $\mathrm{S}^{2}=$ 320.11 and minimum of $S^{2}=244.52$, relative to annual variations, as observed by Dallacort et al. (2011) for the municipality of Tangará da Serra.

The variability in rain can be noted by the difference in rainfall levels between the municipalities. Rondonópolis presents an average of $400 \mathrm{~mm}$ less annual rainfall than the other municipalities studied, but the pattern in ENSO years is similar, with the lower precipitation on El Niño years and highest in neutrals and middle on La Niña (Figure 2).

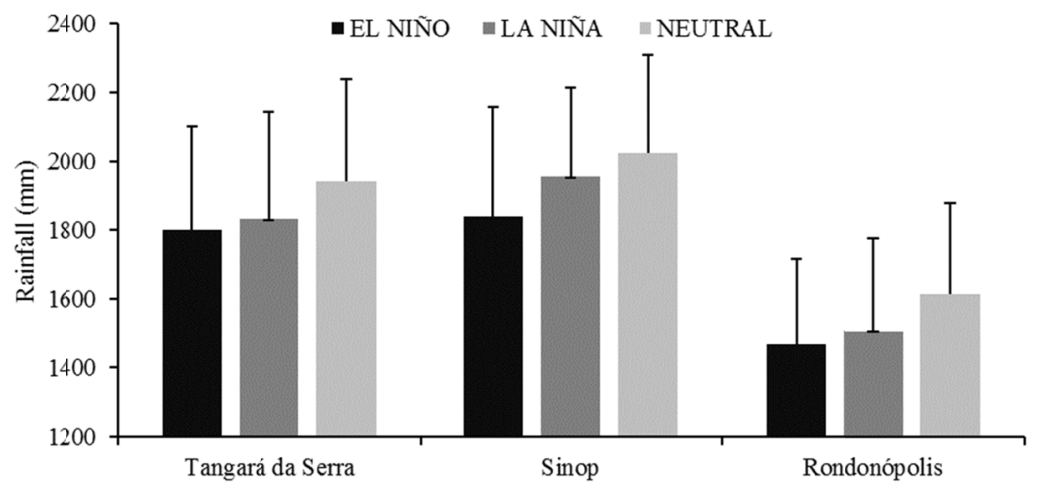

Figure 2. Rainfall averages and annual standard deviation in years with occurrence of El Niño, La Niña and Neutral Years for Tangará da Serra, Sinop and Rondonópolis

The monthly averages over the years characterize the two distinct phases in the pattern of rainfall in the region: one rainy, from October to April, and the other dry, from May to September, as is expected for the central region of Brazil. This pattern is caused by the movement of hot and humid air masses formed in the Pacific Ocean and brought by the trade winds. Some authors have already observed these patterns for regions in Mato Grosso state, such as Dallacort et al. (2011), in a study carried out in the municipality of Tangará da Serra, and Pizzato et al. (2012) and Ramos et al. (2015), who studied the pattern of rains in the municipalities of Cáceres and Diamantino (Figure 3).

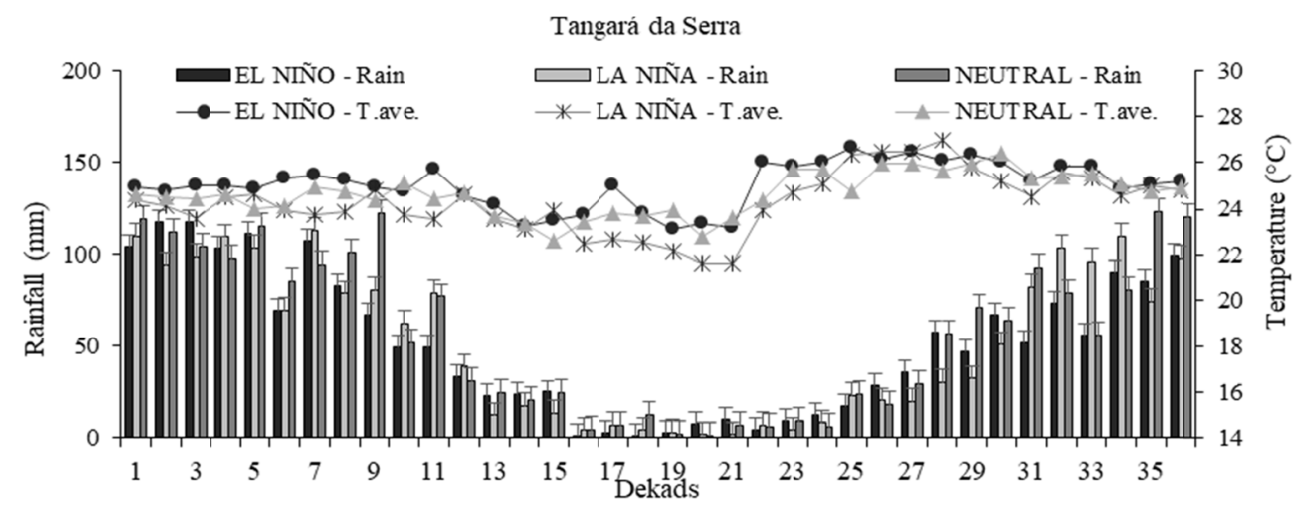

Figure 3. Ten-days means of rain and temperature in years of El Niño, La Niña and Neutrals for the municipality of Tangará da Serra-MT

In the municipality of Tangará da Serra, it is possible to observe higher average monthly and dekads temperatures in El Niño years. Neto, Barbosa, and Araújo (2007) claim that high air temperatures increase the temperature of the Pacific and this warming of up to $3{ }^{\circ} \mathrm{C}$ in the ocean water is characterized as an El Niño event, which subsequently causes intense rains but with long periods of drought in the central west region of Brazil. 
For Tangará da Serra, the beginning of the rainy period in September and October has the highest rainfall indices in El Niño years. This pattern consequently favors the cultivation of large crops such as soybean and corn, providing evidence for bringing forward the planting of soybean and.

On a dekads scale, we can observe the occurrence of veranicos in the last dekads of November for Neutral and El Niño years, which can cause losses in productivity when planting is carried out close to this period. According to Bergamaschi et al. (2004), corn productivity is a result of the hydric conditions present in the critical period for the crop, namely flourishing and grain filling, and at this stage veranicos cannot occur.

During El Niño years, the highest average temperatures are found in the last dekads of February until the first dekads of September, a period in which the drought begins, with high temperatures and low rainfall.

In the municipality of Rondonópolis, we can also observe that in El Niño years, the rains begin in September, with an average of $71 \mathrm{~mm}$ for this month (Figure 4). According to Moreira et al. (2015), despite the municipalities being spatially distant, their climatic characteristics present small variabilities. However, Dallacort et al. (2011) report that within the Mato Grosso State, there is great climatic variability between the regions given the diversity of biomes.

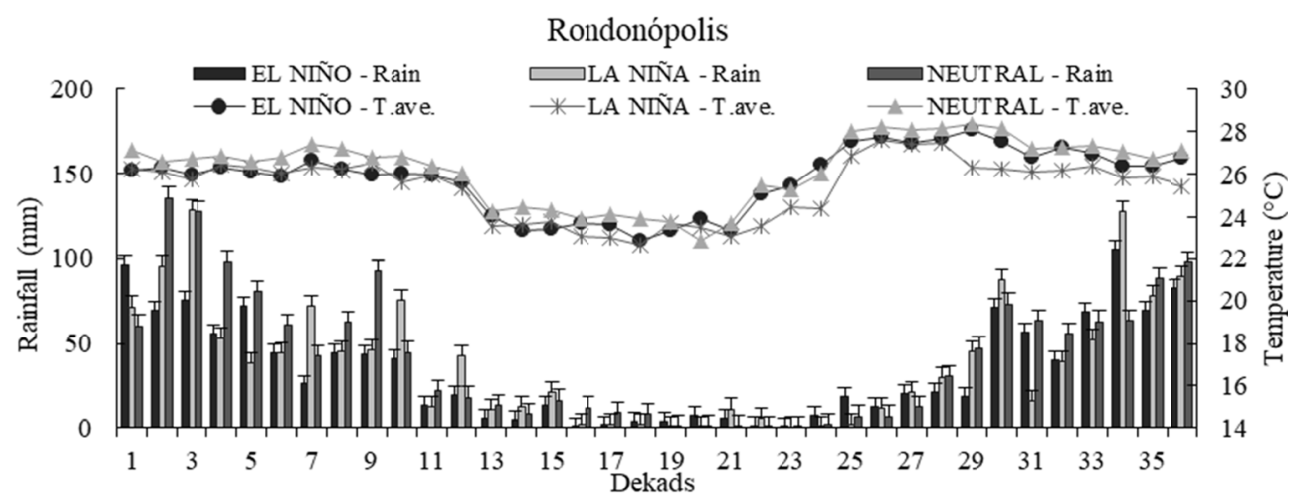

Figure 4. Dekads means of rain and temperature in years of El Niño, La Niña and Neutral for the municipality of Rondonópolis-MT

For years in which La Niña occur, the precipitation index reaches $164 \mathrm{~mm}$ in the month of April, not passing a monthly average of $72 \mathrm{~mm}$ for the other events. Thus, in La Niña years, planting should be adapted so that the most water demanding development stages coincide with this period, decreasing the risk of losses from hydric deficit, as prescribed by Bergamaschi et al. (2004) for corn, who concluded that corn productivity, irrespective of the regional climatic condition, is the result of the hydric conditions present in the critical period for the crop.

The current outlook for the state, according to data gathered by CONAB (2016), is that the "little" or second harvest corn crop is increasing its area every year, and for the crop to develop adequately, rains need to occur in the flourishing and grain filling phase (critical phase).

In El Niño years, it is important to stress that veranicos occur in dekads 31, which can coincide with the critical phase for soy, directly affecting its productivity. Studies that calculate the probability of rains in producer municipalities are of the upmost importance for planning the best period for planting.

In the municipality of Sinop, we can observe that the average temperature pattern follows the same tendency as in the municipality of Rondonópolis, where the highest averages occur in Neutral years, with an average annual maximum of $27^{\circ} \mathrm{C}$, followed by years of El Niño.

Monthly rainfall in Sinop presents a similar pattern to that of Tangará da Serra, where the variability in years with the ENSO effect is small, with variations in the month of November, with a total precipitation of $317 \mathrm{~mm}$ compared with $225 \mathrm{~mm}$ for El Niño and Neutral years.

The monthly rainfall level in Sinop presents a similar pattern to that in Tangará da Serra, in which the effect of variability in years of ENSO phenomenon is small and presents variations in precipitations in the month of November, having a total of $317 \mathrm{~mm}$ compared to El Niño and Neutral years, in which the total was $225 \mathrm{~mm}$ (Figure 5). 


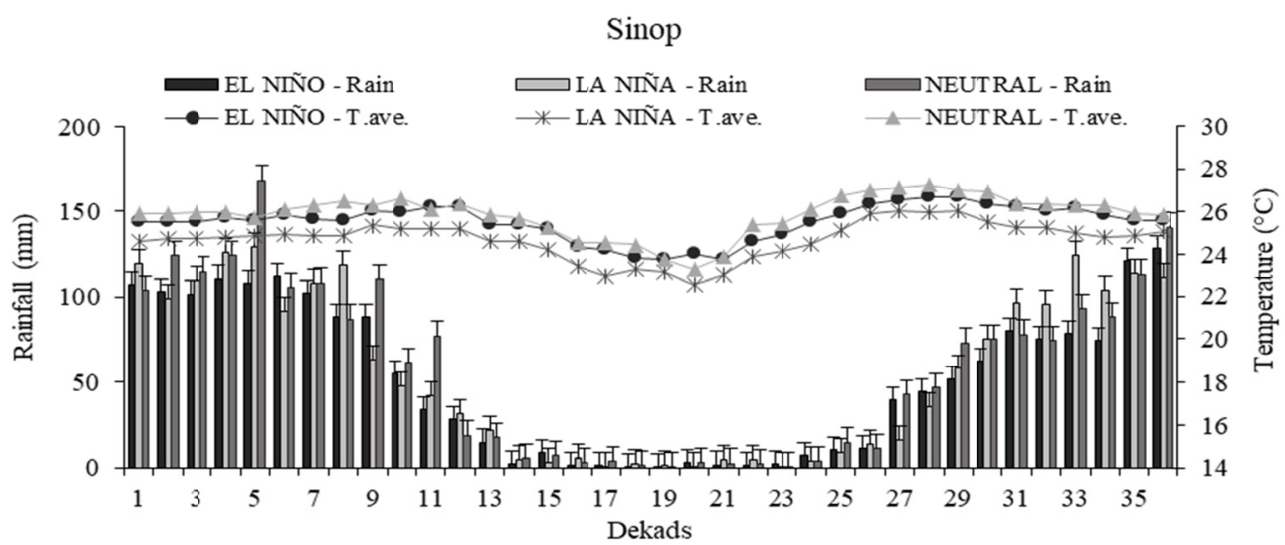

Figure 5. Dekads means of rain and temperature in years of El Niño, La Niña and Neutral for the municipality of Sinop-MT

Dekads $30,31,32,33$, and 34 in La Niña years present lower rainfall levels compared with the other events. In this period, soy planting occurs in Mato Grosso state. According to Amudha and Balasubramani (2011), in this phase, hydric scarcity imposes abiotic stresses, which are the most important factors in limiting the productive capacity of the plant, and based on this, the artificial supply of water, via irrigation, is an important tool for mitigating the impacts of climatic fluctuations on agricultural production.

Considering that corn crops present the highest hydric demand in the period covering pre-flourishing to grain filling, Silva et al. (2007) claims that obtaining high crop productivity in the second harvest in the region is directly linked to the period of planting; the later this is, the higher the risks of failure in this activity.

\subsection{Precipitation Probability}

In Table 2, it is observed that the values calculated in all the events are lower than the critical values tabulated, suggesting that there is agreement between the frequencies observed and expected. The exception was the municipality of Tangará da Serra in La Niña years, in which there were many faults in the data collection, making efficiency of the test impossible. Other authors have also found adjustments of the Gamma Distribution in their studies in various locations (Moreira et al., 2010; Ramos et al., 2015).

Table 2. Values of $\alpha$ and $\beta$, mean and standard deviation of annual precipitation data

\begin{tabular}{llllllll}
\hline Municipality & Event & $\alpha$ & $\beta$ & D. M. Calc. & D. M. Tab. & $\overline{\boldsymbol{X}}$ & $\mathrm{S}^{2}$ \\
\hline \multirow{3}{*}{ Tangará da Serra } & EL NINO & $\mathbf{3 7 . 4 3}$ & $\mathbf{4 9 . 1 3}$ & $\mathbf{0 . 1 5 1 6 1}$ & $\mathbf{0 . 2 1 2 9 7}$ & 1802 & $\mathbf{3 0 0 . 5 9}$ \\
& LA NINA & $\mathbf{3 5 . 4 7}$ & $\mathbf{5 2 . 3 0}$ & $\mathbf{0 . 2 8 2 5 6}$ & $\mathbf{0 . 2 4 1 9 3}$ & 1830 & $\mathbf{3 1 1 . 4 9}$ \\
& NEUTRAL & $\mathbf{3 2 . 1 0}$ & $\mathbf{5 2 . 6 4}$ & $\mathbf{0 . 1 0 7 4 0}$ & $\mathbf{0 . 2 0 1 9 0}$ & 1940 & $\mathbf{2 9 8 . 2 4}$ \\
\hdashline & EL NINO & $\mathbf{3 3 . 7 4}$ & $\mathbf{5 5 . 1 1}$ & $\mathbf{0 . 2 0 3 0 5}$ & $\mathbf{0 . 2 1 2 9 7}$ & 1838 & $\mathbf{3 2 0 . 1 1}$ \\
\multirow{3}{*}{ Sinop } & LA NINA & $\mathbf{5 9 . 1 4}$ & $\mathbf{3 3 . 6 5}$ & $\mathbf{0 . 1 4 8 0 9}$ & $\mathbf{0 . 2 4 1 9 3}$ & 1953 & $\mathbf{2 5 8 . 7 8}$ \\
& NEUTRAL & $\mathbf{5 9 . 5 3}$ & $\mathbf{3 2 . 6 2}$ & $\mathbf{0 . 1 5 5 9 2}$ & $\mathbf{0 . 2 1 9 2 3}$ & 2024 & $\mathbf{2 5 1 . 6 8}$ \\
\hdashline & EL NINO & $\mathbf{3 5 . 8 6}$ & $\mathbf{4 1 . 3 3}$ & $\mathbf{0 . 1 8 4 6 3}$ & $\mathbf{0 . 2 1 2 9 7}$ & 1468 & $\mathbf{2 4 7 . 5 0}$ \\
\multirow{3}{*}{ Rondonópolis } & LA NINA & $\mathbf{2 7 . 3 6}$ & $\mathbf{5 2 . 1 4}$ & $\mathbf{0 . 1 5 9 1 0}$ & $\mathbf{0 . 2 4 1 9 3}$ & 1505 & $\mathbf{2 7 2 . 7 2}$ \\
& NEUTRAL & $\mathbf{3 0 . 5 5}$ & $\mathbf{4 4 . 2 4}$ & $\mathbf{0 . 1 7 9 0 1}$ & $\mathbf{0 . 1 8 4 0 9}$ & 1614 & $\mathbf{2 4 4 . 5 2}$ \\
\hline
\end{tabular}

According to Morais et al. (2001), previous knowledge of the probability of precipitation guarantees greater certainty in planning supplementary irrigation systems and even in expanding agricultural production, enabling greater efficiency in hydric resource utilization.

Bernardo (1995) claims that the parameter generally used for the dimensioning of irrigation systems is average rainfall and taking into consideration years in which the ENSO phenomenon occurs. Its effects can demand greater water supply capacity since, according to the author, a precipitation probability of at least $75 \%$ should be used for this purpose.

According to Dallacort et al. (2011), studying rainfall distribution and its probability of occurrence for the next 
months or years is becoming more and more relevant in agricultural planning. By knowing the minimum level of precipitation in the region with a margin of certainty, planning about planting periods and efficient use of supplementary irrigation can be carried out, obtaining better use of available water and ensuring reliability in decision making.

In Table 3, we can observe that the municipalities of Sinop and Tangara da Serra present higher precipitations in La Niña years. As for Rondonópolis, the highest precipitations are found in El Niño years.

Table 3. Probable annual rainfall for municipalities in years of El Niño, La Niña and Neutral

\begin{tabular}{lllllll}
\hline \multirow{2}{*}{ Municipality } & \multirow{2}{*}{ Event } & \multicolumn{4}{c}{ Annual rainfall probable (mm) } \\
\cline { 3 - 6 } & & $10 \%$ & $25 \%$ & $50 \%$ & $75 \%$ & $90 \%$ \\
\hline \multirow{3}{*}{ Sinop } & EL NINO & $\mathbf{2 2 7 9 . 7}$ & $\mathbf{2 0 6 4 . 2}$ & $\mathbf{1 8 4 1 . 1}$ & $\mathbf{1 6 3 4 . 7}$ & $\mathbf{1 4 6 2 . 8}$ \\
& LA NINA & $\mathbf{2 3 2 8 . 2}$ & $\mathbf{2 1 5 8 . 1}$ & $\mathbf{1 9 7 9 . 0}$ & $\mathbf{1 8 1 0 . 0}$ & $\mathbf{1 6 6 6 . 6}$ \\
\multirow{3}{*}{ Tangará da Serra } & NEUTRAL & $\mathbf{2 2 7 0 . 6}$ & $\mathbf{2 1 0 5 . 2}$ & $\mathbf{1 9 3 1 . 0}$ & $\mathbf{1 7 6 6 . 7}$ & $\mathbf{1 6 2 7 . 1}$ \\
& EL NINO & $\mathbf{2 2 3 3 . 3}$ & $\mathbf{2 0 3 1 . 9}$ & $\mathbf{1 8 2 2 . 7}$ & $\mathbf{1 6 2 8 . 4}$ & $\mathbf{1 4 6 5 . 9}$ \\
& LA NINA & $\mathbf{2 2 6 3 . 9}$ & $\mathbf{2 0 5 4 . 7}$ & $\mathbf{1 8 3 7 . 7}$ & $\mathbf{1 6 3 6 . 7}$ & $\mathbf{1 4 6 8 . 8}$ \\
\multirow{3}{*}{ Rondonópolis } & NEUTRAL & $\mathbf{2 0 8 1 . 4}$ & $\mathbf{1 8 8 0 . 2}$ & $\mathbf{1 6 7 2 . 2}$ & $\mathbf{1 4 8 0 . 2}$ & $\mathbf{1 3 2 0 . 6}$ \\
& EL NINO & $\mathbf{1 8 0 6 . 8}$ & $\mathbf{1 6 4 0 . 7}$ & $\mathbf{1 4 6 8 . 4}$ & $\mathbf{1 3 0 8 . 5}$ & $\mathbf{1 1 7 5 . 1}$ \\
& LA NINA & $\mathbf{1 7 8 5 . 2}$ & $\mathbf{1 5 9 9 . 7}$ & $\mathbf{1 4 0 9 . 1}$ & $\mathbf{1 2 3 4 . 3}$ & $\mathbf{1 0 9 0 . 0}$ \\
\hline
\end{tabular}

Comparing with the results from Ramos et al. (2015), who quantified the rains in Diamantino, a municipality close to those studied, the highest rainfall levels were observed in Neutral years, followed by El Niño, with La Niña having the lowest levels. The pattern of the rains thus differs from region to region. Besides the variability in rains found during ENSO events, we can observe that the municipality of Sinop presents the highest probable rainfall level compared to the others, and Rondonópolis presents the lowest probable rainfall level.

With relation to the probability of monthly rains, we can observe in Figure 6 that, in January, Tangará da Serra presents the highest probability in El Niño years, with the probable volume of precipitation decreasing monthly. As for La Niña, there is little variation between January, February, and March, with it decreasing markedly in April and May; however, there is a peak in rainfall levels in November. For Neutral years, the rainiest months are February and March, with a $90 \%$ probability that in the months of May to September, no precipitations occur. 
Sinop
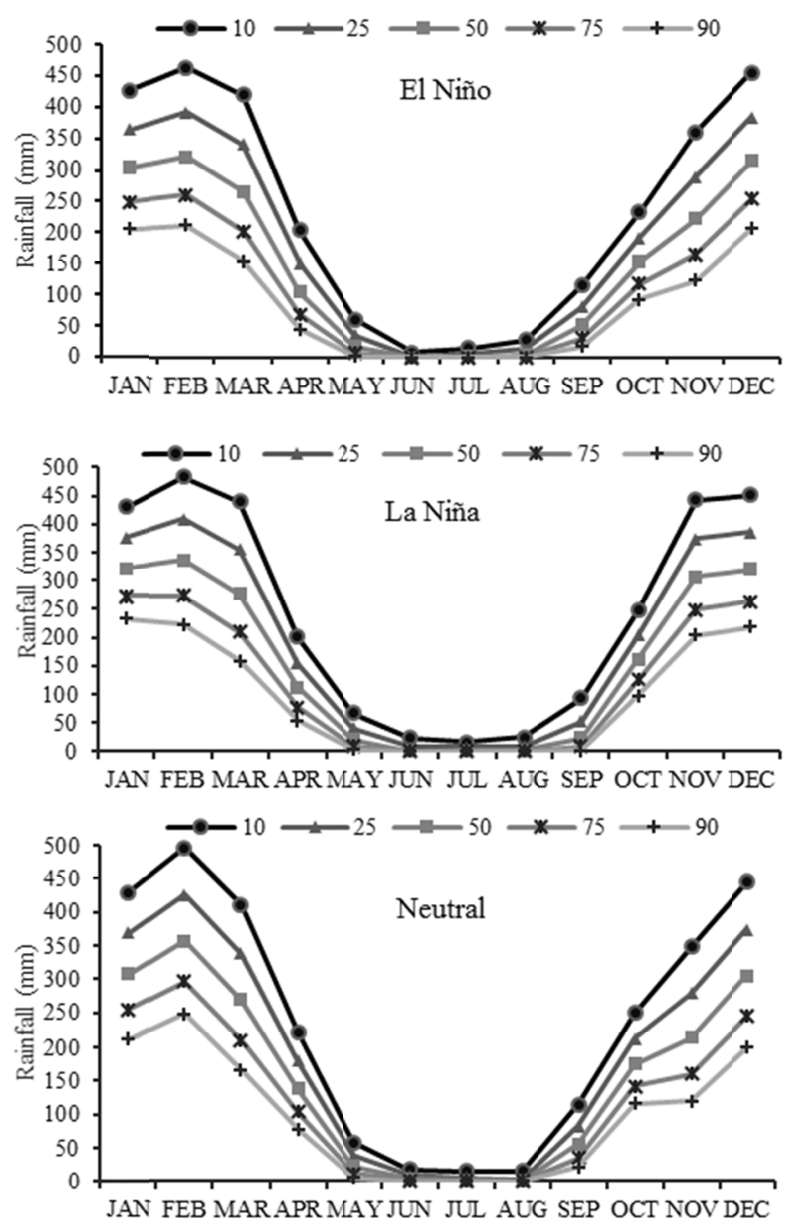

Tangará da Serra
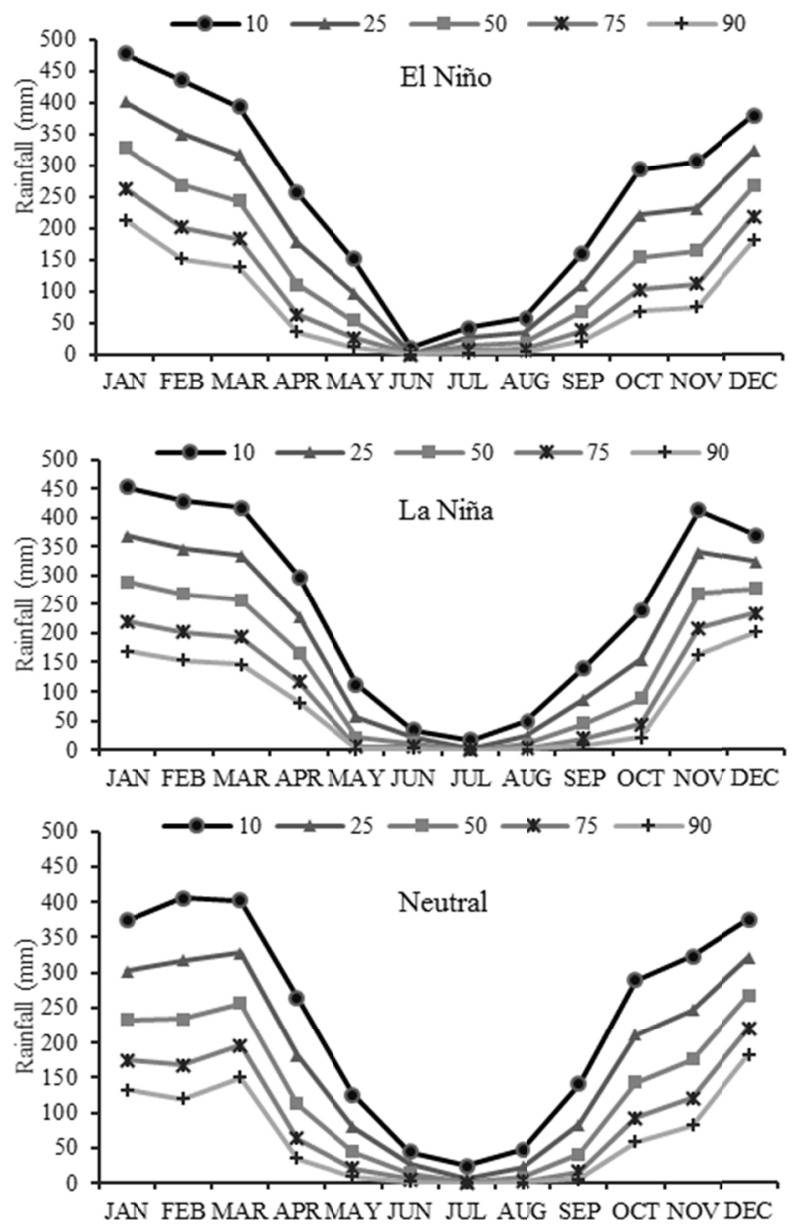

Rondonópolis
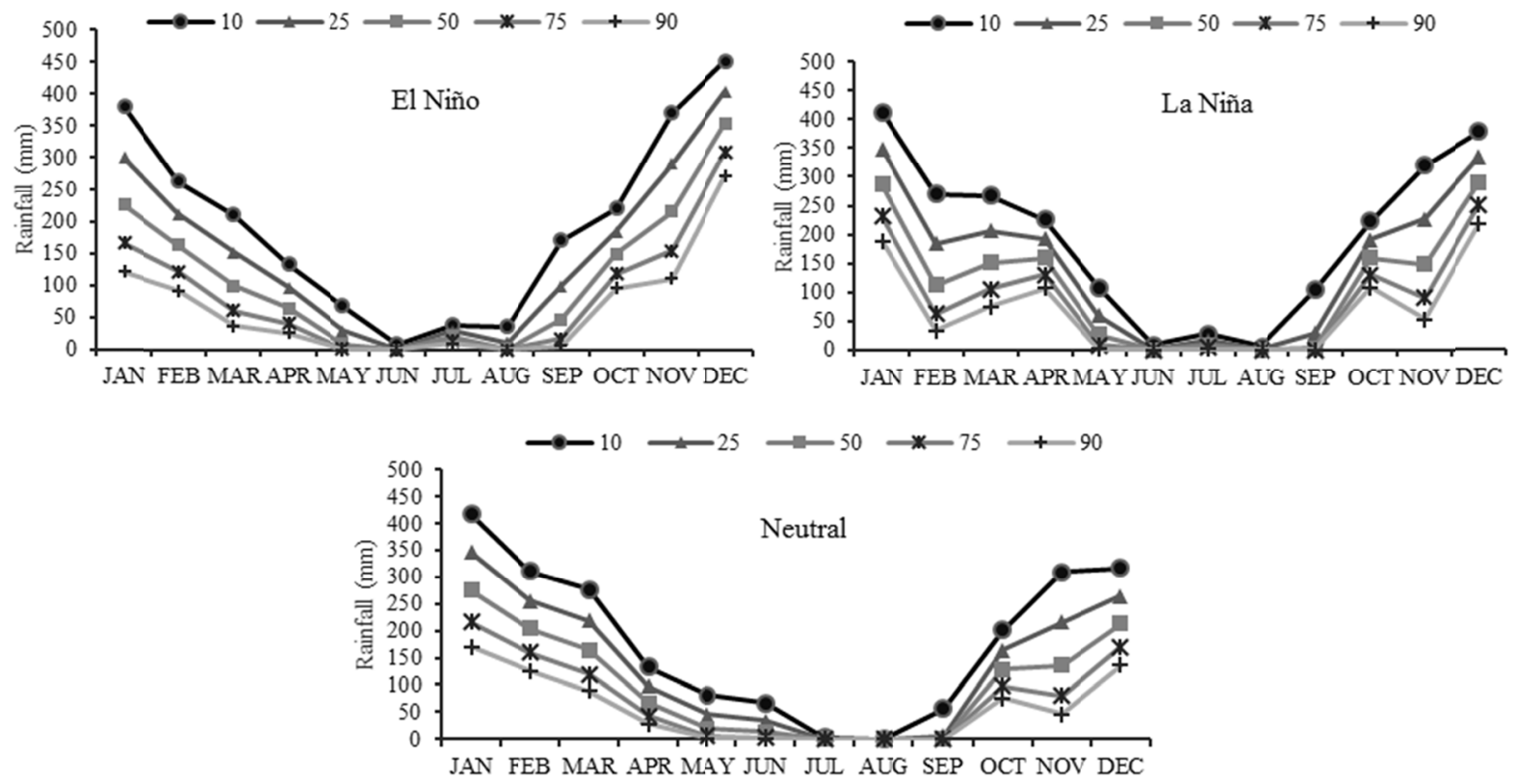

Figure 6. Probability levels (\%) of monthly rainfall in years of El Niño, La Niña and Neutral in the three municipalities studied

For the municipality of Sinop, the months with the highest rainfall levels are January and December for all the 
events. At La Niña times, there is a longer period of drought, covering May to September, with a $90 \%$ probability of less than $10 \mathrm{~mm}$ of rain occurring. As for the other events, in September there is a $90 \%$ probability of $30 \mathrm{~mm}$ of accumulated rainfall.

This pattern is expected for the state and its regions, as researched by Dallacort et al. (2011) in Tangará da Serra, where they claim that the rainy period for the municipality covers October to March and the dry period falls between April and September.

The municipality of Rondonópolis presents higher rainfall in December for El Niño and in January for La Niña and Neutral years. For La Niña events, veranicos occur in November and February, with a $90 \%$ probability of accumulated rainfall below $30 \mathrm{~mm}$ occurring for both months.

According to Bergamashi et al. (2004), veranicos in February or March can favor soy harvests; however, they prescribe planting second harvest corn, requiring planning and analysis of the pattern of rains in the region.

\subsection{Quantification of Dry and Rainy Days}

For the three municipalities studied, the months of December, January, February, and March were the ones that presented the highest average number of rainy days (Figures 7, 8, and 9). Similar results were observed by various authors who have carried out studies in different regions of the state (Pizzato et al., 2012; Moreira et al., 2010; Ramos et al., 2015).

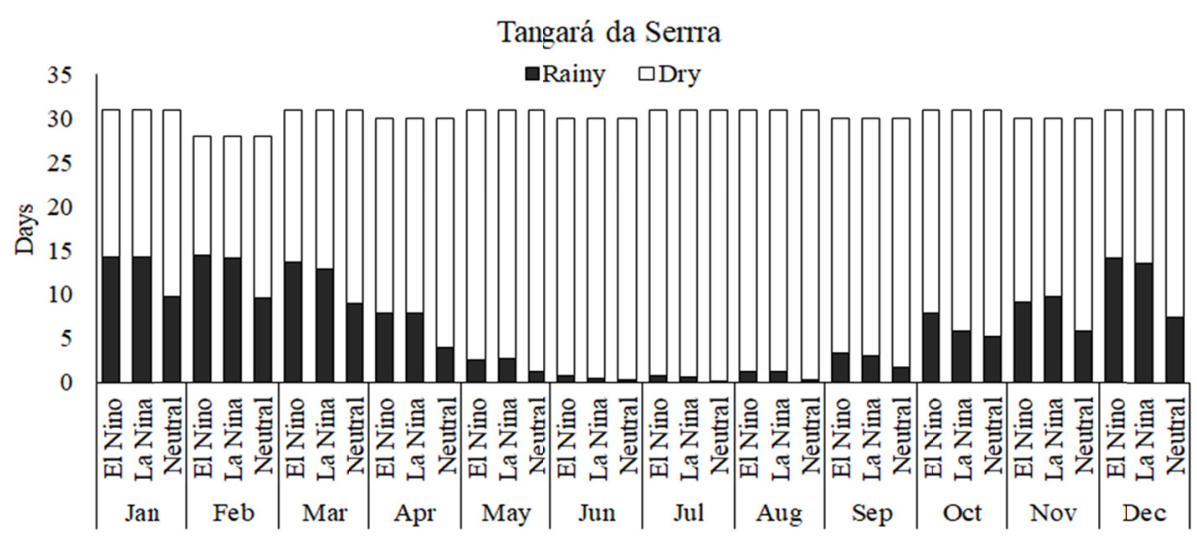

Figure 7. Monthly distribution of dry and rainy days in years of El Niño, La Niña and Neutral for Tangará da Serra-MT

For the municipalities of Tangará da Serra and Sinop, Neutral years present the lowest values for rainy days, followed by La Niña and El Niño years, which present a higher number of rainy days. With regards to rainfall levels, we observe that Neutral years present higher levels, and the intensity of rains in these years are thus greater, results which support those observed by Ramos et al. (2015), who claim that higher intensity rains are found in Neutral years.

The number of dry and rainy days in Rondonópolis present lower variability in relation to the other municipalities studied. We can note that in La Niña years, the number of rainy days is greater than in El Niño and Neutral years.

For the three municipalities, the months of June, July, and August present less than one day of rain on average, which according to Dallacort et al. (2011) characterizes the dry period of the year for these regions. 


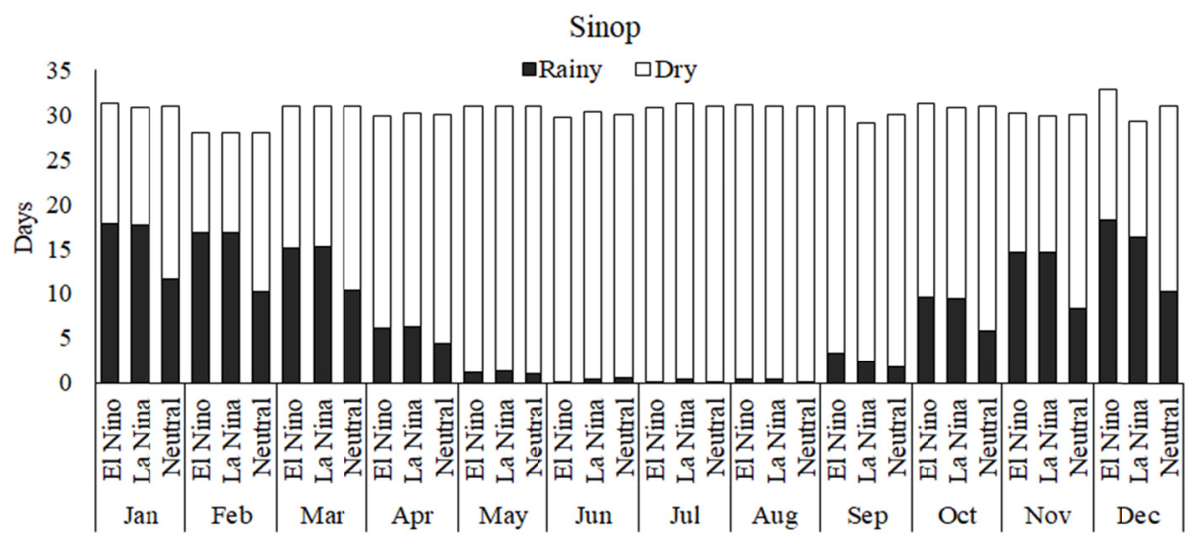

Figure 8. Monthly distribution of dry and rainy days in years of El Niño, La Niña and Neutral for Sinop-MT

The average annual number of rainy days in Tangará da Serra is 89, 86, and 54 in El Niño, La Niña, and Neutral years, respectively. For Rondonópolis, the annual average is 70, 81 and 69 for years of El Niño, La Niña and Neutral respectively. In Sinop, it is 103, 101, and 64 for El Niño, La Niña, and Neutral years, respectively. In Neutral years, despite the average annual volume of precipitation being higher, the number of rainy days is lower, with it being concluded that during this event, the intensity of rains is greater (Figure 9).

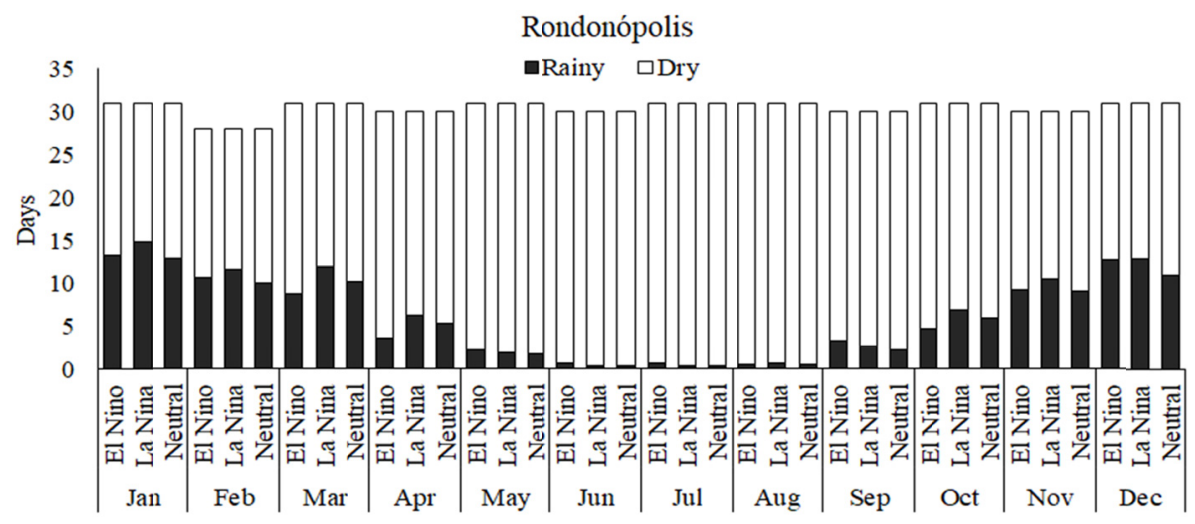

Figure 9. Monthly distribution of dry and rainy days in years of El Niño, La Niña and Neutral for Rondonópolis-MT

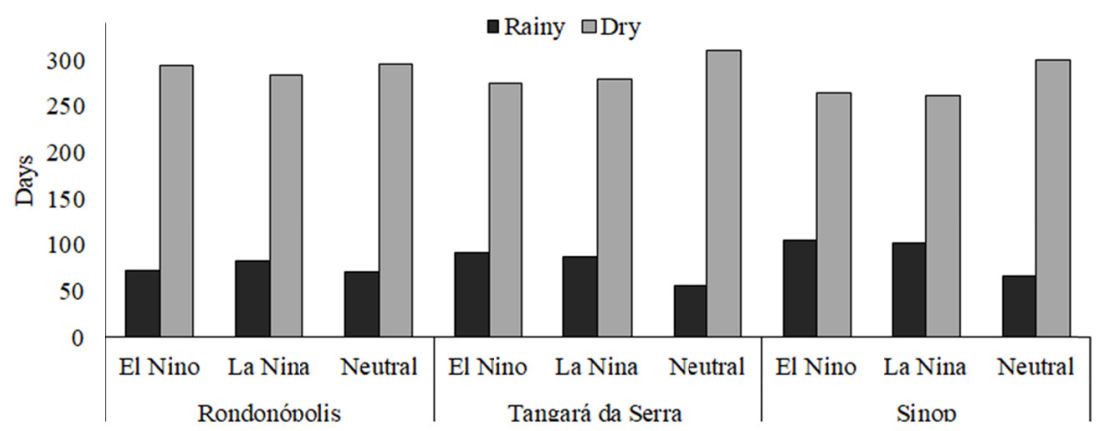

Figure 10. Annual distribution of dry and rainy days in El Niño, La Niña and Neutral for the three municipalities studied

When studying the El Niño and La Niña phenomena, Oliveira, Marcuzzo, and Barros (2015) observed that in the months in which they were most intense, the tendency curves remained practically stable; that is, there was no tendency for an increase or decrease in the number of rainy days within the period being studied. 


\section{Conclusion}

The municipalities of Tangará da Serra, Rondonópolis, and Sinop present higher rainfall levels in Neutral years, and the effects of the ENSO reduce rainfall levels, but increase the number of rainy days.

The effects of the ENSO present a similar pattern in the three municipalities, with the presence of veranicos in La Niña years and more concentrated rains in El Niño years.

In Neutral years, the intensity of rains is greater, and the number of rainy days is lower, providing evidence of the occurrence of veranicos with periods of more than 8 days without rain.

In La Niña years are observed the lowest mean air temperature in all regions studied.

The Neutral years are more suitable to agriculture at regions of Mato Grosso State, followed by El Niño years, with concentrated rainy period and La Niña, with higher occurrence of veranicos, that maybe mitigated with use of irrigations systems.

This work can be used in government planning, as well as in rural insurance and agricultural financing.

\section{References}

Amudha, J., \& Balasubramani, G. (2011). Recent molecular advances to combat abiotic stress tolerance in crop plants. Biotechnology and Molecular Biology Review, 6, 31-58.

Alves, E. B. B. M., Jacovine, L. A. G., Lima, G. S., Bontempo, G. C., \& Torres, C. M. M. E. (2017). As mudanças climáticas e a produção agropecuária: Percepção dos produtores rurais da região da Zona da Mata Mineira, Brasil. Revista Espacios, 38, 24.

Assis, F. N., Arruda, H. V., \& Pereira, A. R. (1996). Aplicações de estatística à climatologia: Teoria e prática (1st ed.). Pelotas, RS: Universidade Federal de Pelotas.

Bergamaschi, H., Dalmago, G. A., Bergonci, J. I., Bianchi, C. A. M., Müller, A. G., Comiran, F., \& Heckler, B. M. M. (2004). Distribuição hídrica no período crítico do milho e produção de grãos. Pesquisa Agropecuaria Brasileira, 39, 831-839. https://doi.org/10.1590/S0100-204X2004000900001

Berlato, M. A., Farenzena, H., \& Fontana, D. C. (2005). Associação entre El Niño Oscilação Sul e a produtividade do milho no Estado do Rio Grande do Sul. Pesquisa Agropecuaria Brasileira, 40, 423-432. https://doi.org/10.1590/S0100-204X2005000500001

Berlato, M. A., \& Fontana, D. C. (2003). El Niño e La Niña: Impactos no clima, na vegetação e na agricultura do Rio Grande do Sul: Aplicações de previsões climáticas na agricultura (1st ed.). Porto Alegre, RS: UFRGS.

Bernardo, S. (1995). Manual de irrigação (6th ed.). Viçosa, MG: Imprensa Universitária.

Câmara, G. M. de S. (2012). Introdução ao agronegócio soja. Piracicaba, SP: USP/ESALQ. Retrieved from http://www.esalq.usp.br/departamentos/lpv/sites/default/files/LPV\%200506\%20-\%20Soja\%20Texto\%2001 $\% 20-\% 20 \% 20$ Agronegocio.pdf

CONAB (Companhia Nacional de Abastecimento). (2016). Acompanhamento da safra brasileira. Acompanhamento de safra brasileira: Grãos, nono levantamento. Retrieved from http://www.conab.gov.br/ OlalaCMS/uploads/arquivos/16_06_10_14_42_08_boletim_graos_maio_2016_-_final.pdf

Dallacort, R., Martins, J. A., Inoue, M. H., Freitas, P. S. L., \& Coletti, A. J. (2011). Distribuição das chuvas no município de Tangará da Serra, médio norte do Estado de Mato Grosso, Brasil. Acta Scientiarum Agronomy, 33, 193-200. https://doi.org/10.4025/actasciagron.v33i2.5838

Faria, R. T., Chibana, E. Y., \& Caramori, P. H. (2003). Programa computacional para organização e análise de dados meteorológicos. Engenharia Agrícola, 23, 372-387.

Grimm, A. M., Barros, V. R., \& Doyle, M. E. (2000). Climate variability in Southern South America associated with El Niño and La Niña events. Journal of Climate, 13, 35-58. https://doi.org/10.1175/1520-0442(2000) $013<0035$ :CVISSA $>2.0 . \mathrm{CO} ; 2$

Marinho, H. M. A., Cândido, L. M., Cândido, S. D. E. A., Daltro, O., Jaudi, L. M. R., Camargo, E. J., \& Yoshida, P. S. (2016). Análise econômica da evolução do agronegócio em mato grosso no período de 1990 a 2010. Revista Faipe, 6, 13-24. 
Morais, A. R., Botelho, V. A., Carvalho, L. G., Muniz, J. A., \& Lage, G. (2001). Estimativa da precipitação provável em Lavras (MG) através da distribuição gama. Revista Brasileira de Agrometeorologia, 9, 305-310.

Moreira, P. S. P., Dallacort, R., Galvanin, E. A. dos S., Neves, R. J., Carvalho, M. A. C. de, \& Barbieri, J. D. (2015). Ciclo diário de variáveis meteorológicas nos biomas do estado de mato grosso. Revista Brasileira de Climatologia, 17, 173-188. https://doi.org/10.5380/abclima.v17i0.41159

Moreira, P. S. P., Dallacort, R., Magalhães, R. A., Inoue, M. H., Stieler, M. C., Silva, D. J. Da, \& Martins, J. A. (2010). Distribuição e probabilidade de ocorrência de chuvas no município de Nova Maringá-MT. Revista de Ciências Agro-Ambientais, 8, 9-20.

Neto, J. M. D. M., Barbosa, M. P., \& Araújo, A. E. de. (2007). Efeito dos eventos ENOS e das TSM na variação pluviométrica do semi-árido paraibano. Revista Brasileira de Engenharia Agrícola e Ambiental, 11, 61-66. https://doi.org/10.1590/S1415-43662007000100008

Oliveira, N. D. L., Marcuzzo, F. F. N., \& Barros, R. G. (2015). Influência do El Niño e La Niña no número de dias de precipitação pluviométrica no Estado do Mato Grosso. Ciência e Natura, 37, $284-297$. https://doi.org/10.5902/2179460X12717

Pizzato, J. A., Dallacort, R., Tieppo, R. C., Modolo, A. J., Cremon, C., \& Moreira, P. S. P. (2012). Distribuição e probabilidade de ocorrência de precipitação em cáceres (MT). Pesquisa Agropecuária Tropical, 42, 137-142. https://doi.org/10.1590/S1983-40632012000200006

Ramos, H. Da C., Dallacort, R., Santi, A., Junior, S. S., \& Queiroz, T. De M. (2015). Precipitação pluvial de Diamantino-MT em anos de ocorrência de El niño, La niña e Neutros. Revista Brasileira de Meteorologia, 30, 71-80. https://doi.org/10.1590/0102-778620120477

Sans, L. M. A., Assad, D., Guimarães, D. P., \& Avelar, G. (2001). Zoneamento de riscos climáticos para a cultura do milho na região centro-oeste do Brasil e para o estado de Minas Gerais. Revista Brasileira de Agrometeorologia, 9, 527-539.

Silva, J. C., Heldwein, A. B., Martins, F. B., Trentin, G., \& Grimm, E. L. (2007). Análise de distribuição de chuva para Santa Maria, RS. Revista Brasileira de Engenharia Agrícola Ambiental, 11, 67-72. https://doi.org/10.1590/S1415-43662007000100009

Thom, H. C. S. (1958). A note on the gama distribution. Monthly Weather Review, 86, 117-122. https://doi.org/ 10.1175/1520-0493(1958)086<0117:ANOTGD>2.0.CO;2

\section{Copyrights}

Copyright for this article is retained by the author(s), with first publication rights granted to the journal.

This is an open-access article distributed under the terms and conditions of the Creative Commons Attribution license (http://creativecommons.org/licenses/by/4.0/). 